\title{
A Comparison of the Cell Walls of Pediococcus cerevisiae and of a Substrain that Requires Methicillin for Growth
}

\author{
By P. J. WHITE* \\ Twyford Laboratories, Twyford Abbey Road, London, N.W. Io
}

(Accepted for publication 4 July 1967)

\begin{abstract}
SUMMARY
Cell walls were prepared from: (I) Pediococcus cerevisiae 808I grown (in partly defined medium) without methicillin; (2) P. cerevisiae 8081 grown with a sub-inhibitory concentration of methicillin (Io $\mu \mathrm{g} . / \mathrm{ml}$.); (3) P. cerevisiae 808I CRD (methicillin-dependent substrain) grown with an optimal concentration of methicillin (I00 $\mu \mathrm{g} . / \mathrm{ml}$.). All three preparations contained glucosamine, muramic acid, $N$-acetyl groups (no $O$-acetyl groups), alanine, glutamic acid, lysine and aspartic acid, in proportions which suggested that they were components of a mucopeptide polymer; small amounts of serine, glycine and threonine were also present. The mucopeptide components made up about $50 \%$ by weight of walls (I) and (2) but about $80 \%$ in walls (3). Glucose and phosphorus were present in the walls, in greater amounts in walls (I) and (2) than in walls (3). No free amino groups were detected in any of the walls, and most of the lysine was released as $\epsilon$-(aminosuccinyl)-lysine when mucopeptide from the parent strain was hydrolysed for a short period. About $35 \%$ of walls (I) and (2) was removed by extraction at $2^{\circ}$ with trichloroacetic acid; only I $6 \%$ was removed from walls (3). Nearly all the glucose and most of the phosphorus was removed from all the walls by such extraction; the residues after extraction all contained about $90 \%$ of mucopeptide components. Teichoic acids were isolated from each trichloroacetic acid extract: phosphorus, glucose, alanine and glycerol were found in all. Teichoic acid from walls (3) contained, in addition, about $7 \%$ of mucopeptide components. Walls and trichoroacetic acid insoluble residues from the methicillin-dependent substrain were hydrolysed much more rapidly by lysozyme than were walls or residues of the parent strain, whether grown in absence or presence of methicillin.
\end{abstract}

\section{INTRODUCTION}

A substrain of Pediococcus cerevisiae has been obtained which requires methicillin (or some other penicillins) for growth, and some properties of the substrain have now been examined (White, 1967). It seemed possible that changes in the chemical composition of the cell wall might accompany the development of this growth requirement for a penicillin, since interference with the biosynthesis of the cell wall is thought to be a primary effect of penicillins on susceptible bacteria (see review by Reynolds, 1966). The composition of cell walls of $P$. cerevisiae has already been investigated by Ikawa \& Snell (1960). In the present study, walls of this organism, grown in the absence and in the presence of methicillin, were re-examined, and were compared with walls of the methicillin-dependent substrain. A preliminary report of this work has already been given (White, I966).

* Present address: Department of Microbiology, The University, Western Bank, Sheffield, Io. 


\section{METHODS}

Organisms. Pediococcus cerevisiae ATCC 808 I and the methicillin-dependent substrain ( $P$. cerevisiae $808 \mathrm{I}$ CRD) were maintained as described previously (White, 1967).

Medium and growth of organisms. The partly defined medium (containing leucovorin) for Pediococcus cerevisiae was that used by White \& Nichol (1963). The parent strain was grown in the absence of methicillin or in the presence of a sub-inhibitory concentration of it (I0 $\mu \mathrm{g}$. $/ \mathrm{ml}$.). Pediococcus cerevisiae 808I CRD was grown in the presence of methicillin ( $100 \mu \mathrm{g}$. $/ \mathrm{ml}$.). In each case, ten 21 . flasks, each containing I 1 . medium, were autoclaved at $120^{\circ}$ for $15 \mathrm{~min}$., cooled, and sterile methicillin was added when required. Each flask was inoculated with $\mathrm{I} \mathrm{ml}$. of an overnight culture, then was left to stand at $37^{\circ}$. Organisms were harvested by centrifugation after 2 days (parent strain) or 4 days (methicillin-dependent substrain), by which time fairly heavy growth had been reached. The organisms were washed once in $0.9 \%$ sodium chloride and once in water, then were resuspended in water. The dry weight of this suspension was found (by heating a sample to constant weight at $105^{\circ}$ ); water was added to the suspension as required to give about equiv. $20 \mathrm{mg}$. dry wt organisms $/ \mathrm{ml}$.

Isolation of cell walls. The organisms were broken in a shaker head (Shockman, Kolb \& Toennies, 1957) fitted on a PR 2 centrifuge (International Equipment Co., Boston, Mass., U.S.A.) as described by Allsop \& Work (I963). Immediately after breaking, the containers were heated for $10 \mathrm{~min}$. at $60^{\circ}$ (to inactivate lytic enzymes) before the glass beads were removed by filtration through a coarse sintered glass filter. The filtrate was centrifuged for $5 \mathrm{~min}$. at $400 \mathrm{~g}$. The supernatant liquid (containing cell walls) was centrifuged at $20,000 \mathrm{~g}$ for $20 \mathrm{~min}$., and the pad was washed twice with water. The pad was resuspended in $0.05 \mathrm{M}$-tris $\mathrm{HCl}$ buffer $(\mathrm{pH} \mathrm{7.8;200} \mathrm{ml}$.) containing crude trypsin ( $\mathrm{I}$ g.) and one drop of chloroform. The suspension was shaken gently overnight at $37^{\circ}$, and then was centrifuged at $400 \mathrm{~g}$ for $5 \mathrm{~min}$. The supernatant liquid (containing cell walls) was centrifuged at $20,000 \mathrm{~g}$ for $20 \mathrm{~min}$. The walls were washed twice with $\mathrm{I} \cdot 0 \mathrm{M}$-sodium chloride, twice with $0.05 \mathrm{M}$-tris $\mathrm{HCl}$ buffer $(\mathrm{pH} \mathrm{7.8)}$ and six times with water, with centrifugation at 20,000 $\mathrm{g}$ for $20 \mathrm{~min}$. between each wash. The walls were dried on a grid, and examined without further preparation in the electron microscope (by Dr Hilary Rose). Very many empty cell-evelopes were seen, while no whole organisms were found. The walls were freezedried and finally dried over phosphorus pentoxide in vacuum and weighed.

Isolation of teichoic acids. This was based on the procedure of Shaw \& Baddiley (1964). About $250 \mathrm{mg}$. dry walls were suspended in $10 \%(\mathrm{w} / \mathrm{v})$ trichloroacetic acid $\left(20 \mathrm{ml}\right.$.) at $2^{\circ}$ and stirred continuously for I week at $2^{\circ}$. The suspension was centrifuged at $20,000 \mathrm{~g}$ for $10 \mathrm{~min}$. at $2^{\circ}$ and the solid residue extracted as before with a further $20 \mathrm{ml}$. Io \% trichloroacetic acid. The solid residue after this extraction was washed twice in water, then resuspended in water, freeze-dried and weighed. The combined extracts were shaken three times with ether ( $15 \mathrm{ml}$.) to remove trichloroacetic acid. Nitrogen was bubbled through the aqueous layer to remove ether, and then the solution was freeze-dried. The solid was redissolved in $10 \%(\mathrm{w} / \mathrm{v})$ trichloroacetic acid $\left(5 \mathrm{ml}\right.$ ) at $2^{\circ}$ and ethanol ( $5 \mathrm{ml}$.) was added. The precipitate was left to settle at $2^{\circ}$ overnight. The supernatant liquid was decanted, more ethanol $(25 \mathrm{ml}$.) was added to it and the precipitate was left to settle at $2^{\circ}$ overnight. The combined precipitates were dissolved (in a weighed tube) in $10 \%(\mathrm{w} / \mathrm{v})$ trichloroacetic acid $\left(3 \mathrm{ml}\right.$.) at $2^{\circ}$, ethanol 
( $5 \mathrm{ml}$.) was then added and the precipitate allowed to settle at $2^{\circ}$ overnight. The precipitate was washed with acetone and then with ether and was dried in vacuum over phosphorus pentoxide.

Amino acid analysis. Cell walls or teichoic acids (about $5 \mathrm{mg}$.) were heated at $105^{\circ}$ in sealed tubes for $\mathrm{I} 8 \mathrm{hr}$ with $6 \mathrm{~N}-\mathrm{HCl}$ ( $\mathrm{I} \mathrm{ml}$.). The acid was removed by drying in vacuum over phosphorus pentoxide and sodium hydroxide, then adding water and drying twice more. The dried residue was taken up in $0.1 \mathrm{~N}-\mathrm{HCl}$ (ro ml.) and the amino acids in a sample determined by use of a Technicon AutoAnalyser (Technicon Instruments Co. Ltd, Hanworth Lane, Chertsey, Surrey).

Amino sugars. Cell walls or teichoic acids (about $5 \mathrm{mg}$.) were heated at $100^{\circ}$ in sealed tubes for $4 \mathrm{hr}$ with $4 \mathrm{~N}-\mathrm{HCl}$ ( $\mathrm{I} \mathrm{ml}$.). The acid was removed as above, and the residues taken up in water ( $\mathrm{I} \mathrm{ml}$.). Total hexosamine (glucosamine and muramic acid) in the hydrolysate was estimated by the borate method of Strominger, Park \& Thompson (1959). Glucosamine was estimated by the method of Cessi \& Piliego (1960) in which muramic acid does not react. Attempts to estimate muramic acid by the method of Ghuysen \& Strominger (1963) were unsuccessful, as were attempts to separate glucosamine and muramic acid on charcoal + Celite columns (Perkins \& Rogers, 1959). Consequently the amount of glucosamine was subtracted from the total hexosamine to give a value for muramic acid.

Glucose. Cell walls or teichoic acids (about $5 \mathrm{mg}$.) were heated at $100^{\circ}$ in sealed tubes for $\mathrm{I} \mathrm{hr}$ with $0.5 \mathrm{~N}-\mathrm{HCl}$ ( $\mathrm{I} \mathrm{ml}$.). The acid was removed by drying in vacuum as above, and the residues taken up in water (I ml.). Glucose in these solutions was estimated with a Glucostat kit (Worthington Biochemical Corporation, Freehold, N.J., U.S.A.).

Phosphorus. The method of Fiske \& SubbaRow (1929) was used to estimate total phosphorus. Inorganic phosphorus was estimated by the method of Lipman \& Tuttle (1944).

Acetyl groups. The method of Ludowieg \& Dorfman (1960) was used to estimate total acetyl groups $(O$ - and $N$-). To estimate $N$-acetyl groups, cell walls (about $25 \mathrm{mg}$.) were stirred overnight in $0.0 \mathrm{I} \mathrm{N}-\mathrm{NaOH}(2 \mathrm{ml}$.) at room temperature to remove $O$-acetyl groups, and then washed three times with water. The washed walls were dried and weighed before acetyl groups (i.e. $N$-acetyl) were estimated as before. No difference between total acetyl groups and $N$-acetyl groups was found, so that no $O$-acetyl groups were present in the walls.

Determination of free amino groups. (H. R. Perkins, personal communication, based on the method of Ingram \& Salton, 1957.). Cell walls $(5 \mathrm{mg}$.) were suspended in 0.I M-ammonium acetate, $\mathrm{pH} \mathrm{6.5} \mathrm{(5} \mathrm{ml.).} \mathrm{The} \mathrm{walls} \mathrm{of} \mathrm{Pediococcus} \mathrm{cerevisiae} \mathrm{808I}$ (grown in the absence or presence of methicillin) readily formed an even suspension when they were rubbed with a glass rod in the buffer. Walls of $P$. cerevisiae 808 I CRD, however, were not dispersed so easily; instead small flakes were formed which settled from suspension very quickly. A more even suspension of these walls was made by ultrasonic treatment for a minute or two in an MSE $60 \mathrm{~W}$ ultrasonic disintegrator (Measuring and Scientific Instruments Ltd, 25-28 Buckingham Gate, London, S.W. I).

The suspension of walls $\left(0.3 \mathrm{ml}\right.$.), I \% (w/v) $\mathrm{Na}_{2} \mathrm{~B}_{4} \mathrm{O}_{7} \cdot \mathrm{IOH}_{2} \mathrm{O}$ (borax) $(\mathrm{I} \cdot 2 \mathrm{ml}$.) and $0.1 \mathrm{M}$ - I-fluoro-2,4-dinitrobenzene ( $0.15 \mathrm{ml}$. in ethanol) were rapidly mixed in a test-tube $\left(150 \times 15 \mathrm{~mm}\right.$.), and the mixture was heated at $60^{\circ}$ for $30 \mathrm{~min}$. After cooling, unreacted fluorodinitrobenzene was removed by extraction three times with ether $(2 \mathrm{ml}$.) and traces of ether removed from the aqueous layer with a stream of nitrogen. The walls were 
centrifuged $(20,000 \mathrm{~g}$ for Io min.) and washed once in water to remove borax, then resuspended in $4 \mathrm{~N}-\mathrm{HCl}\left(2 \cdot 25 \mathrm{ml}\right.$.) and heated in a sealed tube at $100^{\circ}$ for $4 \mathrm{hr}$. After cooling, the contents of the tube were diluted with water $(2 \cdot 25 \mathrm{ml}$.). The extinction of this solution was measured at $420 \mathrm{~m} \mu$ in a $2 \mathrm{~cm}$. cuvette against a zero of water, in order to assess roughly the amount of DNP-amino acids that had been formed. A calibration curve was established with DNP-alanine for which $\epsilon$ was found to be $6.5 \times 10^{3}$. The solution was extracted as before with ether to remove any DNP-derivatives of acidic and neutral amino acids. Both this extract and the aqueous residue (which should contain DNP-derivatives of basic amino acids) were evaporated to dryness and taken up in $50 \%$ (v/v) ethanol in water (I00 $\mu \mathrm{l}$.). The solutions $(20 \mu \mathrm{l}$.) were spotted onto a thin-layer chromatography plate (silica gel), which was developed with chloroform + methanol+acetic acid $(95+5+\mathrm{I}$ by vol.) for about $\mathrm{I} \mathrm{hr}$ at room temperature. The solutions in dilute ethanol ( $20 \mu \mathrm{l}$.) were also examined by electrophoresis on Whatman no. 3 paper in $0 . \mathrm{I} \mathrm{M}$-sodium carbonate at $500 \mathrm{~V}$ for $3 \mathrm{hr}$.

Digestion with lysozyme. Cell walls ( $5 \mathrm{mg}$.) were suspended evenly (as above) in $0.1 \mathrm{M}$-ammonium acetate ( $\mathrm{pH} \mathrm{6.5;4.75} \mathrm{ml}$ ) at $2 \mathrm{I}^{\circ}$, in a colorimeter tube (15 mm. diameter). One drop of $0.9 \%$ sodium chloride was added. At time zero, $0.25 \mathrm{ml}$. of a solution of lysozyme in $0 \cdot 1 \mathrm{M}$-ammonium acetate $\left(\mathrm{I} \mathrm{mg}\right.$. $/ \mathrm{ml}$.) was added at $2 \mathrm{I}^{\circ}$. The turbidity of the suspension was measured at intervals in an EEL colorimeter (Evans Electroselenium Co. Ltd, Halstead, Essex) against a zero of water, using a neutral density filter (no. $\mathrm{I} \cdot \mathrm{O})$.

Chromatography. For preliminary investigation of the amino acids present in hydrolysates of cell walls, two-dimensional chromatograms (on Whatman no. 4 paper) were run, using as solvents: (I) phenol saturated with water, with a few drops of concentrated ammonia solution and a few crystals of potassium cyanide added to the tank; (2) butan-I-ol + acetic acid + water $(67+10+23$, by vol.). After development, the chromatograms were treated with ninhydrin (0.1\%) in acetone.

To detect hexosamines, chromatograms (on Whatman no. I paper) were irrigated with ethyl acetate + pyridine + acetic acid + water $(5+5+\mathrm{I}+3$, by vol.; Fischer $\&$ Nebel, I955). After development, chromatograms were treated with ninhydrin (as above) or with the reagents for hexosamines described by Partridge (1948), which however gave only weak spots.

For detection of carbohydrates, chromatograms (on Whatman no. I paper) were developed with butan-I-ol + pyridine + water $(6+4+3$, by vol.) or propan-I-ol + aq. ammonia solution (sp.gr. $0 \cdot 88)+$ water $(6+3+\mathrm{I}$, by vol.). Chromatograms were treated with alkaline silver nitrate (Smith, I960), or, to detect glycols, with periodateSchiff's reagents (Baddiley, Buchanan, Handschumacher \& Prescott, I956).

Electrophoresis. Phosphate esters were separated by electrophoresis (on Whatman no. 3 paper) for about $3 \mathrm{hr}$ at $500 \mathrm{~V}$ and $20 \mathrm{~mA}$, in collidine acetate buffer ( $\mathrm{pH} 7{ }^{\circ} 0$; $0.08 \mathrm{M}$ in respect of $\gamma$-collidine). The method of Hanes \& Isherwood (I949) was used to detect phosphate esters.

Chemicals and enzymes. Bacitracin was a gift from Professor E. P. Abraham, and muramic acid (isolated from cell walls of Micrococcus lysodeikticus) was a gift from Dr H. R. Perkins. Trypsin ('from pancreas') and lysozyme ('crystalline, from egg white') were purchased from British Drug Houses Ltd (Poole, Dorset). Alkaline phosphatase ('from Escherichia coli, salt-fractionated') was purchased from Worthington Biochemical Corporation (Freehold, N.J., U.S.A.). 


\section{RESULTS \\ Cell walls}

Batches of cell walls were isolated from the parent strain grown without methicillin, and from the methicillin-dependent substrain grown in the presence of the drug (I00 $\mu \mathrm{g} . / \mathrm{ml}$.); one batch of walls was also examined from the parent strain grown in the presence of a sub-inhibitory concentration of methicillin ( $10 \mu \mathrm{g} . / \mathrm{ml}$.) in order to establish whether such conditions led to changes in the composition of the cell wall. Chromatography showed the presence in each batch of alanine, aspartic acid, glutamic acid, lysine, glucosamine and traces of glycine. Glucosamine and muramic acid were the only hexosamines, and glucose was the only reducing sugar found on chromatography of hydrolysates of the walls. No component was seen in one batch of walls that was not present in the others.

\section{Table I. Composition of the cell walls of Pediococcus cerevisiae 8081 and $808 \mathrm{I} C R D$}

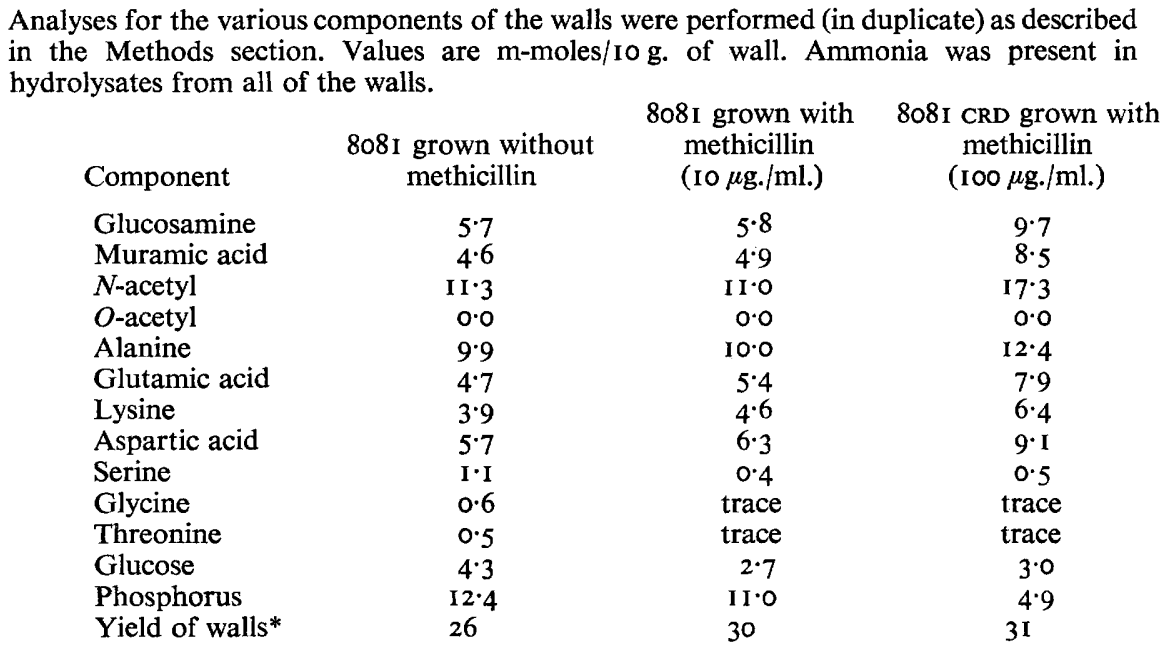

* Percentage of dry weight washed organisms obtained as dry cell walls.

Quantitative analyses for amino acids, hexosamines, acetyl groups, glucose and phosphorus were made, the results of which are shown in Table I. Glucosamine and muramic acid occurred in walls of the parent strain in roughly equimolar amounts, and approximately 2 moles of $\mathrm{N}$-acetyl were present for each 2 moles of hexosamine. No $O$-acetyl groups were detected. Glutamic acid, lysine and aspartic acid were found in amounts roughly equimolar with the muramic acid, and there was a larger amount of alanine. These quantitative relationships strongly suggested that these substances were all components of a mucopeptide polymer (Perkins \& Rogers, I959). Serine, glycine and threonine were found in small amounts: there was considerably less of these compounds in walls of organisms grown in the presence of methicillin. The presence of glucose and phosphorus suggested that the walls contained a teichoic acid (Baddiley \& Davison, I96I). This possibility was confirmed 
when it was found that all the glucose and most of the phosphorus could be removed by trichloroacetic acid, and that teichoic acid could be precipitated from the acid extract.

No marked changes in the composition of the wall were found when the parent strain was grown in the presence of methicillin. However, in walls of the methicillindependent substrain 808I CRD the mucopeptide components made up a larger proportion of the weight than they did in walls of the parent strain $(77 \%$ and $5 \mathrm{I} \%$ in the two strains respectively, allowing for the loss of weight on condensation between components). The walls of the parent strain on the other hand contained more than twice as much phosphorus as did walls of the substrain and a greater weight of material was extracted by trichloroacetic acid from walls of the parent strain.

Ammonia could not be determined in the amino acid analyser, though it was found in hydrolysates of every batch of walls. If the value for ammonia $(3.3 \%, \mathrm{w} / \mathrm{w})$ obtained by Ikawa \& Snell (1960) is taken for walls of the parent strain, and if an amount of glycerol equimolar with the phosphorus extracted by trichloroacetic acid is assumed to be present (see later) and phosphorus is assumed to be present as orthophosphate, then $78 \%$ of the dry wt of the walls of the parent strain (grown without methicillin) can be accounted for as known compounds. If similar assumptions regarding phosphorus and glycerol are made for the walls of the methicillin-dependent substrain (but ammonia be neglected) then account can be made for $90 \%$ of the dry wt of these walls.

In case the observed differences between parent and methicillin-dependent strains were no more than chance variations between different batches of walls, further samples of walls of the parent strain (grown without methicillin) and of the substrain were isolated. Hydrolysates of these walls were found chromatographically to be closely similar to those from the earlier batches. Analyses for hexosamines, glucose and phosphorus showed that in the new samples there was again a higher proportion of mucopeptide and less teichoic acid in the walls of the substrain than in walls of the parent strain.

\section{Analysis of residues after extraction of cell walls with trichloroacetic acid}

After extraction, the residues were made up very largely of the mucopeptide components, and the difference between the residues from the parent strain and the substrain were slight (Table 2). If acetyl groups equimolar with the total hexosamines were assumed to be present in the residues, it was possible to account for $92 \%$ of the dry weight of the residue from the parent strain (grown without methicillin) and for $91 \%$ of the dry weight of the residue from the substrain, as mucopeptide components. Almost all the glucose was extracted, but an appreciable amount of phosphorus remained. The way in which this phosphorus is combined is not known.

When hydrolysates of the residues were examined in the amino acid analyser a peak was found on the recorder trace near the position where tryptophan or 3-methylhistidine would be expected. It seemed possible that this material might be $\epsilon$-(aminosuccinyl)-lysine, which has been shown to be formed by cyclization of aspartic acid and lysine when bacitracin or cell walls of lactobacilli are heated with hydrochloric acid (Swallow \& Abraham, 1958). After hydrolysis of a sample of bacitracin (5 mg.) at $105^{\circ}$ for $6 \mathrm{hr}$ with $6 \mathrm{~N}-\mathrm{HCl}(\mathrm{I} \mathrm{ml}$.), a peak was found in the same position on the recorder trace as the unknown compound; the other peaks were all identifiable as 
amino acids that are present in bacitracin: aspartic acid, lysine, glutamic acid, isoleucine, leucine, phenylalanine, ornithine, histidine.

Cell-wall residues hydrolysed in $6 \mathrm{~N}-\mathrm{HCl}$ for various times at $105^{\circ}$ were analysed for aspartic acid and lysine and for the unknown compound (Table 3). As the times

\section{Table 2. Composition of residues after extraction of cell walls of Pediococcus} cerevisiae 808I and 808I CRD with trichloroacetic acid

Analyses for the various components of the residues were performed (in duplicate) as described in the Methods section. Acetyl groups were not estimated. Values are m-moles/10 g. of residue. Ammonia was present in hydrolysates of all the residues.

\begin{tabular}{|c|c|c|c|}
\hline Component & $\begin{array}{l}\text { 8081 grown without } \\
\text { methicillin }\end{array}$ & $\begin{array}{l}\text { 808 I grown with } \\
\text { methicillin } \\
(1 \circ \mu \mathrm{g} . / \mathrm{ml} .)\end{array}$ & $\begin{array}{l}\text { 808 I CRD grown with } \\
\text { methicillin } \\
(\mathrm{I} 00 \mu \mathrm{g} . / \mathrm{ml} .)\end{array}$ \\
\hline Glucosamine & $7 \cdot 9$ & $8 \cdot 0$ & I I 4 \\
\hline Muramic acid & $9 \cdot 4$ & $9 \cdot 2$ & $8 \cdot 0$ \\
\hline Alanine & $16 \cdot 8$ & I $8 \cdot 7$ & 15.0 \\
\hline Glutamic acid & 10.6 & $9^{\cdot 8}$ & $9 \cdot 2$ \\
\hline Lysine* & $9 \cdot 6$ & $9 \cdot 3$ & $10 \cdot 1$ \\
\hline Aspartic acid* & $10 \cdot 2$ & $7 \cdot 8$ & $10 \cdot 0$ \\
\hline Serine & $I \cdot O$ & 0.4 & 0.5 \\
\hline Glycine & 0.8 & Trace & Trace \\
\hline Threonine & 0.8 & Trace & Trace \\
\hline Glucose & 0.2 & $0 \cdot I$ & 0.2 \\
\hline Phosphorus & $2 \cdot 4$ & $2 \cdot 2$ & $I \cdot 6$ \\
\hline Loss of wt. on & 34 & 38 & I6 \\
\hline
\end{tabular}

* After hydrolysis in $6 \mathrm{~N}-\mathrm{HCl}$ for $30 \mathrm{hr}$ at $105^{\circ}$.

$\dagger$ Percentage of dry weight of walls removed by extraction with trichloroacetic acid.

Table 3. Release of aspartic acid and lysine from e-(aminosuccinyl)-lysine after prolonged acid hydrolysis of mucopeptide from Pediococcus cerevisiae $808 \mathrm{I}$

Cell wall residue (after extraction with trichloroacetic acid) was hydrolysed in $6 \mathrm{~N}-\mathrm{HCl}$ at $105^{\circ}$ for various times, and the hydrolysates were examined in the Technicon AutoAnalyser. Values are m-moles/ro g. of residue.

\section{Period of} hydrolysis

(hr)

6
18
30

Aspartic
acid
$3 \cdot 5$
$8 \cdot 2$
$10 \cdot 2$

Lysine
$4 \cdot 7$
$7 \cdot 2$
$9 \cdot 6$

$\begin{array}{rc}\begin{array}{c}\text { Glutamic } \\ \text { acid }\end{array} & \text { Alanine } \\ 9.0 & 15.9 \\ 10.6 & 16.8 \\ 9.4 & 17.0\end{array}$

* Calculated on the assumption that $\epsilon$-(aminosuccinyl)-lysine gave the same colour yield with ninhydrin as was given by norleucine, which was used as a standard.

of hydrolysis were increased, so the yield of the two amino acids went up, while the peak due to the unknown compound decreased. The unknown compound therefore appeared to be $\epsilon$-(aminosuccinyl)-lysine. Its formation on hydrolysis implied that in the wall residues, some molecules of lysine were joined by their $\epsilon$-amino groups to the $\alpha$ - or $\beta$-carboxylic acid groups of aspartic acid. After hydrolysis for $6 \mathrm{hr}$, only about $40 \%$ of the lysine and aspartic acid had been set free, whereas all the alanine and glutamic acid had been liberated. Thus, not less than $60 \%$ of the lysine in the residues was joined by its $\epsilon$-amino group to a carboxylic acid group of aspartic acid. 
No $\epsilon$-(aminosuccinyl)-lysine was found in the hydrolysates of unextracted walls for which analytical data are given in Table I. However, this compound was detected in the amino acid analyser after unextracted cell walls had been hydrolysed for about I $2 \mathrm{hr}$ in $6 \mathrm{~N}-\mathrm{HCl}$. On two-dimensional chromatograms treated with ninhydrin $\epsilon$-(aminosuccinyl)-lysine gave an extended spot close to lysine.

\section{T'eichoic acid}

Results of analyses are shown in Table 4. Glucose, phosphorus (calculated as orthophosphate) and alanine made up $60 \%$ of the dry weight of the teichoic acid from the parent strain, and $74 \%$ of that of the methicillin-dependent substrain; glucose was the major component by weight. Teichoic acid from the parent strain grown in the presence of methicillin was only examined chromatographically.

\section{Table 4. Composition of the teichoic acid from Pediococcus cerevisiae $808 \mathrm{I}$ and $808 \mathrm{I}$ CRD}

Analyses for the various components of the teichoic acids were performed as described in the Methods and Results sections. Values are mmoles/10 g. teichoic acid.

\section{Component}

Glucose

Phosphorus

Alanine

Glycerol

Ammonia

Glucosamine

Muramic acid

Glutamic acid

Lysine

Aspartic acid

Serine

Glycine

Threonine

Yield of teichoic acid*
808 I grown without methicillin

I8.9
28.0
3.6
Present
Present
0.2
0.2
$<0.1$
0.1
0.1
0.2
0.1
Trace
55

808I CRD grown with methicillin (100 $\mu \mathrm{g} . / \mathrm{ml}$.)

* Percentage (by weight) of material extracted from cell walls by trichloroacetic acid recovered as teichoic acid.

Chromatograms of acid hydrolysates of the teichoic acid from the methicillindependent Pediococcus cerevisiae strain 808 I CRD, developed in ethyl acetate + pyridine + acetic acid + water and treated with ninhydrin, showed the presence of hexosamines and other mucopeptide components. These compounds (estimated in the AutoAnalyser) made up $7 \%$ of the dry weight of this teichoic acid (Table 4 ), but were present only in traces in the teichoic acid from the parent $P$. cerevisiae 808I (grown with or without methicillin). The mucopeptide components were not removed from the teichoic acid of $P$. cerevisiae 808I CRD when a solution was passed through a column of Sephadex G-25. Fractions from the column were assayed for phosphorus, and the fractions from the peak of phosphorus content were combined and evaporated. After hydrolysis, the mucopeptide components were still present in the same proportions relative to the phosphorus. This suggested that the mucopeptide was covalently bound to the teichoic acid.

Glucose was the principal sugar found in the teichoic acids. Faint unidentified spots, situated between glucose $\left(R_{F}\right.$ about 0.4$)$ and the origin line, were seen on chromato- 
grams developed in butan-I-ol + pyridine + water and treated with alkaline silver nitrate.

With all the teichoic acids an unexpected difficulty was that the presence of glycerol or ribitol (or anhydroribitol) was not shown chromatographically in acid hydrolysates $\left(2-4 \mathrm{hr}\right.$ at $105^{\circ}$ in $2 \mathrm{~N}$ - or $\left.4 \mathrm{~N}-\mathrm{HCl}\right)$. Markers of these compounds on chromatograms were detected with periodate-Schiff reagents, or equally well with alkaline silver nitrate. To release polyols, teichoic acids from Pediococcus cerevisiae 808r (grown without methicillin) and from $P$. cerevisiae 808I CRD (methicillin-dependent) were first hydrolysed for $4 \mathrm{hr}$ in $4 \mathrm{~N}-\mathrm{HCl}$ at $105^{\circ}$. After neutralization part of each hydrolysate (corresponding to about $500 \mu \mathrm{g}$. teichoic acid) was incubated with alkaline

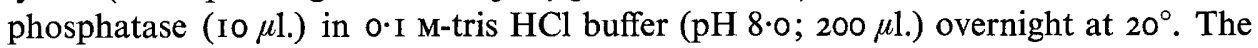
hydrolysates, before and after treatment with the enzyme, were examined by chromatography and paper electrophoresis. The acid hydrolysates contained two principal phosphate esters, one of which corresponded in its position to $\alpha$-glycerophosphoric acid (which moved $10.5 \mathrm{~cm}$. towards the anode after electrophoresis for $3 \mathrm{hr}$ at $\mathrm{pH} 7 \cdot 0$ ) while the other moved $14.5 \mathrm{~cm}$. in the same direction. Two other phosphate esters (which moved $5.5 \mathrm{~cm}$. and $6.8 \mathrm{~cm}$. towards the anode) were present in traces, and inorganic phosphate (which moved $12.5 \mathrm{~cm}$. towards the anode) was also present. After enzymic treatment of the hydrolysates the phosphate esters had disappeared, and all the phosphorus was in the inorganic form; free glycerol was detected but no ribitol or anhydroribitol. Estimations of glucose in the hydrolysates, before and after treatment with alkaline phosphatase, showed that no liberation of free glucose accompanied the release of inorganic phosphate. It was concluded that a glycerolteichoic acid was the only type present in the cell walls, and it has been assumed for quantitative purposes that the glycerol in the teichoic acid is equimolar with the phosphorus. When this assumption was made, $78 \%$ (parent strain) and $96 \%$ (methicillin-dependent substrain) of the dry weight of the teichoic acids could be accounted for as identified compounds.

\section{Determination of free amino groups in cell walls}

No evidence for the presence of free amino groups was obtained with any of the walls since the hydrolysates of walls treated with fluorodinitrobenzene contained no detectable DNP-amino acids. It was thought possible that the walls which had been examined might have lacked free amino groups because the organisms from which the walls were obtained had reached the stationary phase of growth when there was extensive cross-linking of the mucopeptide side-chains. A batch of walls was therefore prepared from Pediococcus cerevisiae 808I CRD harvested in the logarithmic phase of growth. The yield of these walls was only $9 \%$ of the dry weight of the intact organisms, which suggested that the walls were less thick than those of stationaryphase organisms; however, these walls were also devoid of free amino groups.

\section{Digestion by lysozyme of cell walls}

The course of digestion by lysozyme of walls and of residues (after extraction with trichloroacetic acid) is illustrated in Figs. I and 2. The walls of the substrain were rapidly dissolved by lysozyme at $2 \mathrm{I}^{\circ}$, whereas those of the parent strain were more resistant, being lysed at only one tenth of the rate. Walls from the parent strain grown in the presence of methicillin were digested by lysozyme about one and a half 
times more rapidly than those of parent-strain organisms grown in the absence of the drug. Extraction of teichoic acid from the walls did not increase their susceptibilities to attack by lysozyme; in fact the residue from the parent strain (grown without methicillin) was digested only slowly and incompletely at room temperature, although at $37^{\circ}$ overnight digestion almost completely dissolved the residue.

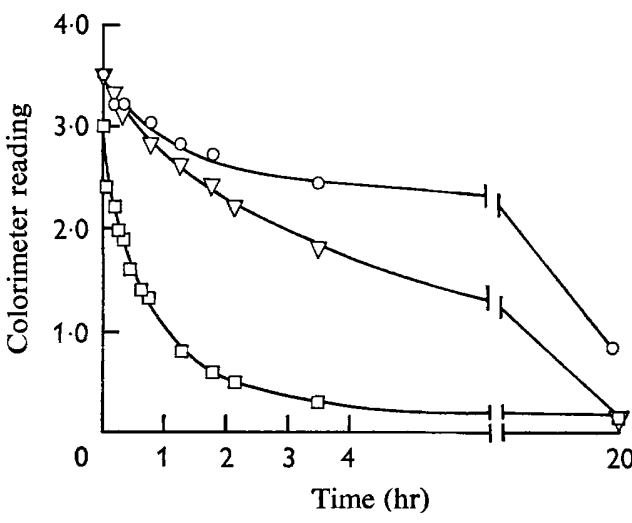

Fig. 1

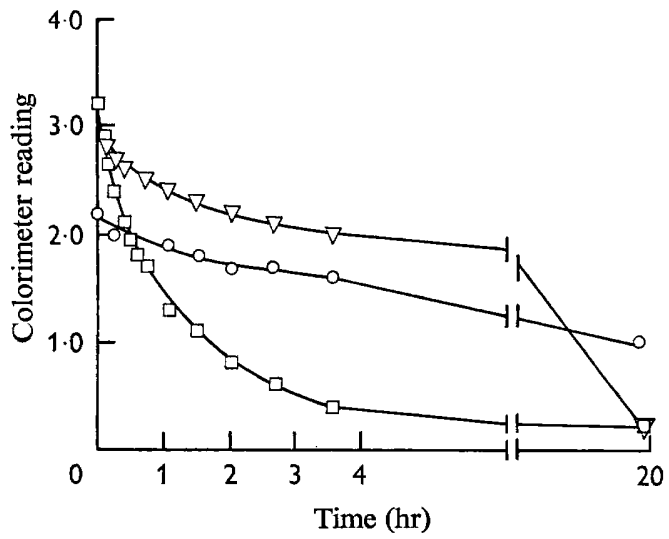

Fig. 2

Fig. I. Digestion by lysozyme ( $100 \mu \mathrm{g} . / \mathrm{ml}$. at $2 \mathrm{I}^{\circ}$ ) of walls of Pediococcus cerevisiae. $\bigcirc, P$. cerevisiae 8081 grown without methicillin; $\nabla, P$. cerevisiae $808 \mathrm{I}$ grown with methicillin ( $10 \mu \mathrm{g} . / \mathrm{ml}.) ; \square P$. cerevisiae $808 \mathrm{I}$ CRD grown with methicillin (100 $\mu \mathrm{g} . / \mathrm{ml}$.).

Fig. 2. Digestion by lysozyme (100 $\mu \mathrm{g} . / \mathrm{ml}$. at $2 \mathrm{I}^{\circ}$ ) of walls of Pediococcus cerevisiae after extraction with trichloroacetic acid. $O, P$. cerevisiae 808I grown without methicillin; $\nabla$, $P$. cerevisiae $808 \mathrm{I}$ grown with methicillin (10 $\mu \mathrm{g} . / \mathrm{ml}$ ); $\square, P$. cerevisiae 808I CRD grown with methicillin ( $100 \mu \mathrm{g} . / \mathrm{ml}$.)

\section{DISCUSSION}

In the present study the results of Ikawa \& Snell (1960) were confirmed in respect of the qualitative composition of the cell walls of Pediococcus cerevisiae 808I. Apart from traces of glycine and threonine no substances were found in these walls other than those reported by Ikawa \& Snell. In the present work, the cell wall made up a higher percentage $(26 \%)$ of the dry weight of the organisms than previously had been found $(9 \%)$. This might be because in the present work the walls were prepared from organisms at a later stage of growth, when the wall had become thickened, or it may be only the result of a difference of efficiency in the method of isolating the walls. Quantitatively, a few differences were found, though on the whole the compositions were similar: Ikawa \& Snell (1960) found more glucose (Io\% of dry wt wall) and less phosphorus $(\mathrm{I} \cdot 4 \%$ ) than were found in the present study (glucose $7 \cdot 7 \%$; phosphorus $3.8 \%$ ).

Growth of Pediococcus cerevisiae 808I in presence of a sub-inhibitory concentration of methicillin did not lead to any marked change in the composition of its cell wall. The walls of the methicillin-dependent $P$. cerevisiae 808I CRD contained the same components as the walls of the parent strain but had relatively more mucopeptide and less teichoic acid. The interpretation of this finding is uncertain. Penicillins are generally considered to inhibit the biosynthesis of mucopeptide, and it may be that in the methicillin-dependent substrain a mechanism of mucopeptide biosynthesis 
operates which is relatively resistant to methicillin; this mechanism might lead to an increase in the proportion of mucopeptide in the wall. Alternatively (or simultaneously) the formation of teichoic acid might be suppressed by methicillin, as some studies might suggest (Saukkonen, 196I; Roberts \& Johnson, 1962; Rogers \& Garrett, 1963).

When teichoic acid had been extracted from the walls, the residues from the parent and methicillin-dependent strains were similar in chemical composition, being made up almost entirely of mucopeptide components. However, there must be differences between the mucopeptides from the two strains since the mucopeptide from Pediococcus cerevisiae $808 \mathrm{I}$ CRD was much more susceptible to hydrolysis by lysozyme than was that from the parent strain. Teichoic acid extracted from walls of $P$. cerevisiae 808 I CRD contained a fragment of mucopeptide. Similar complexes have been isolated from walls of Staphylococcus aureus after partial enzymic degradation (Ghuysen, Tipper \& Strominger, 1965), but these complexes were broken by trichloroacetic acid. Thus, in $P$. cerevisiae 808I CRD some part of the mucopeptide is bound unusually firmly to some of the teichoic acid. Possibly the mucopeptide fragment is separate in the cell wall from the main part of the mucopeptide, which is not soluble in trichloroacetic acid. The data are insufficient to decide whether all the molecules of teichoic acid from $P$. cerevisiae 808I CRD carry a small fragment of mucopeptide or whether a proportion of the teichoic acid molecules carry a relatively large fragment.

Cross-linking in mucopeptide polymers is thought to occur by the formation of a bond between an amino group of a basic amino acid in one peptide chain, and a carboxylic acid group (probably on the terminal alanine) in a neighbouring chain (see review by Rogers, I965). This bond might be formed directly between amino acids that are each in separate peptide chains or through an amino-acid bridge, perhaps aspartic acid in the present case. In either event, the number of free amino groups in a cell wall might be expected to give some measure of the degree of crosslinking of the mucopeptide.

Lysine was the only basic amino acid found in the cell walls of Pediococcus cerevisiae and it was expected that cross-linking of peptide chains might take place through the $\epsilon$-amino group of lysine. Since no amino acid of the mucopeptide was present in considerable molar excess over muramic acid or lysine it seemed unlikely that crosslinking was achieved by a polypeptide bridge, as in Staphylococcus aureus (Petit, Munoz \& Ghuysen, I966). No free amino groups ( $\alpha$ - or $\epsilon-$ ) of lysine or other amino acids were detected in walls of $P$. cerevisiae, and in the parent strain at least $60 \%$ (and possibly much more) of the $\epsilon$-amino groups of lysine were combined with a carboxylic acid group ( $\alpha$ - or $\beta$-) of aspartic acid. These findings suggest that the mucopeptide of the parent strain is cross-linked by an aspartic acid link between lysine and perhaps alanine. However, this point is not established, since the terminal alanine carboxyl groups have not been shown to be bound to aspartic acid in adjacent chains.

Free amino groups would be expected to occur on the alanine residues in the teichoic acid. The alkaline conditions used during the treatment of cell walls with fluorodinitrobenzene would probably liberate this ester-linked alanine into solution, so that the DNP-alanine would be lost when the treated walls were washed with water before hydrolysis.

The absence of free amino groups from the walls does not seem to be a result of 
the walls being isolated from organisms harvested at a late stage of growth, when the wall might have become thickened (Shockman, Kolb \& Toennies, 1958) and extensively cross-linked. Walls from Pediococcus cerevisiae 808I CRD harvested in the logarithmic phase of growth also had no free amino groups, but there was a lower yield of walls from these younger organisms. This suggests that only fully cross-linked walls were isolated by the methods used, and the less cross-linked, more soluble, material from younger organisms might have been lost during the isolation procedure.

If the teichoic acid were concerned in cross-linking of mucopeptide chains, it might be expected (as was found) that walls of the parent strain would be less readily digested by lysozyme, since these walls contain more teichoic acid than do walls of the methicillin-dependent substrain. However, after removal of teichoic acid, the residues from either strain would be expected to show increased, and probably similar, susceptibility to hydrolysis by lysozyme; this was not found to be the case.

Wise \& Park (I965) and Izaki, Matsuhashi \& Strominger (1966) showed that benzylpenicillin inhibited a cross-linking reaction between mucopeptide chains, in Staphylococcus aureus and Escherichia coli, respectively. Professor J. T. Park (personal communication) has suggested that Pediococcus cerevisiae 808I CRD, in the absence of a penicillin, might form a cell wall that was too completely cross-linked, so that the organisms became encased and unable to multiply further. The presence of methicillin (or other penicillins) at a suitable concentration might partly inhibit the formation of cross-links and allow growth to proceed. As this hypothesis would predict, $P$. cerevisiae $808 \mathrm{I}$ CRD did die when the organisms were incubated in the partly defined medium without methicillin. However, the hypothesis does not explain why the organisms did not die in the absence of methicillin when yeast extract was added to the medium; in fact the organisms multiplied in drug-free medium containing yeast extract, provided that sodium acetate was omitted (White, 1967). Another obstacle to the acceptance of this hypothesis is that the cell walls of the parent strain, grown in the presence or absence of methicillin, appear (so far as they have been examined) to be as highly cross-linked as those of the substrain, and yet the organisms were viable when transferred to fresh medium.

Thus the results of the present study, while they reveal some interesting differences between the walls of Pediococcus cerevisiae 808I and its methicillin-dependent substrain 808I CRD, do not lead to an explanation of the requirement for methicillin by $P$. cerevisiae $808 \mathrm{I}$ CRD. Because of the known effect of methicillin on formation of cell walls, it seems reasonable to suppose that the altered features of the walls of $P$. cerevisiae $808 \mathrm{I}$ CRD are related to the metabolic changes which have caused the nutritional requirement for methicillin. However, this might not be the case, since the methicillin-dependent substrain seemed to arise through a number of genetic steps, rather than from a single mutational event (White, 1967).

I am grateful to Dr Elizabeth Work for much valuable advice and criticism, to Dr H. R. Perkins for frequent helpful advice and encouragement, and to Mr M. J. Jackson and Mrs Hélène Theodoseou for technical assistance. Most batches of cell walls were skilfully prepared by $\mathrm{Mr}$ V. Okoro, and the amino acid analyses were done by Mr J. Shaw. Dr Hilary Rose kindly examined cell walls in the electron microscope, and Professor E. P. Abraham (University of Oxford) made a gift of bacitracin. 


\section{REFERENCES}

ALLSOP, J. \& WORK, E. (1963). Cell walls of Propionibacterium species: fractionation and composition. Biochem. J. 87, $5 \mathrm{I} 2$.

Baddiley, J., Buchanan, J. G., Handschumacher, R. E. \& Prescott, J. F. (1956). Biosynthesis of purine nucleotides. I. Preparation of $N$-glycylglycosylamines. J. chem. Soc. p. 28 I 8.

BADDiley, J. \& Davison, A. L. (I96I). The occurrence and location of teichoic acids in lactobacilli. J. gen. Microbiol. 24, 295.

Cessi, C. \& Piliego, F. (1960). Determination of amino sugars in presence of amino acids and glucose. Biochem. J. 77, 508.

FisCher, F. G. \& NEBEL, H. J. (1955). Nachweis und Bestimmung von Glucosamin und Galaktosamin auf Papierchromatogrammen. Hoppe-Seyler's Z. physiol. Chem. 302, 10.

Fiske, C. H. \& SubbaRow, Y. (1929). Phosphocreatine. J. biol. Chem. 81, 629.

GHuYSEN, J.-M. \& Strominger, J. L. (1963). Structure of the cell wall of Staphylococcus aureus strain COPEnhagen. I. Preparation of fragments by enzymatic hydrolysis. Biochemistry 2, il Io.

GHUYSEN, J.-M., TIPPER, D. J. \& STROMINGER, J. L. (1965). Structure of the cell wall of Staphylococcus aureus strain COPENHAGEN. IV. The teichoic acid-glycopeptide complex. Biochemistry 4, 474.

HANES, C. S. \& IsHeRwOOD, F. A. (I949). Separation of the phosphoric esters on the filter paper chromatogram. Nature, Lond. 164, I 107.

IKAWA, M. \& SNell, E. E. (1960). Cell wall composition of lactic acid bacteria. J. biol. Chem. 235, 1376.

IngRAM, V. M. \& SALton, M. R. J. (1957). The action of fluorodinitrobenzene on bacterial cell walls. Biochim. biophys. Acta 24, 9.

IZAKI, K., MATSUHASH, M. \& STrominger, J. L. (1966). Glycopeptide transpeptidase and D-alanine carboxypeptidase: penicillin-sensitive enzymic reactions. Proc. natn. Acad. Sci. U.S.A. 55, 656.

LipmanN, F. \& Tuttle, L. C. (1944). Acetyl phosphate: chemistry, determination, and synthesis. J. biol. Chem. 153, 57 I.

LuDowieg, J. \& DoRFMAN, A. (I960). A micromethod for the colorimetric determination of $N$-acetyl groups in acid mucopolysaccharides. Biochim. biophys. Acta 38, 212.

PARTRIDGE, S. M. (1948). Filter-paper partition chromatography of sugars. I. General description and application to the qualitative analysis of sugars in apple juice, egg white and foetal blood of sheep. Biochem. J. 42, 238.

Perkins, H. R. \& Rogers, H. J. (1959). The products of the partial acid hydrolysis of the mucopeptide from cell walls of Micrococcus lysodeikticus. Biochem. J. 72, 647.

Petit, J.-F., MuN̂oz, E. \& Ghuysen, J.-M. (1966). Peptide cross-links in bacterial cell wall peptidoglycans studied with specific endopeptidases from Streptomyces albus G. Biochemistry 5, 2764.

ReYNolds, P. E. (1966). Antibiotics affecting cell-wall synthesis. Symp. Soc. gen. Microbiol. 16, 47.

RoBerTs, J. \& JoHnson, M. J. (1962). Effect of penicillin on the cell wall of Bacillus subtilis. Biochim. biophys. Acta 59, 458.

Rogers, H. J. (1965). The outer layers of bacteria: the biosynthesis of structure. Symp. Soc. gen. Microbiol. 15, 186.

Rogers, H. J. \& GarRetT, A. J. (1963). The action of benzylpenicillin and cycloserine upon ribitol teichoic acid formation by Staphylococcus aureus. Biochem. J. 88, 6 P.

SAUKKONEN, J. J. (1961). Acid-soluble nucleotides of Staphylococcus aureus: massive accumulation of a derivative of cytidine diphosphate in the presence of penicillin. Nature, Lond. 192, 816.

SHAW, N. \& BADDILEY, J. (I964). The teichoic acid from the walls of Lactobacillus buchneri NCIB 8007. Biochem. J. 93, 317.

Shockman, G. D., Kolb, J. J. \& Toennies, G. (1957). A high speed shaker for the disruption of cells at low temperatures. Biochim. biophys. Acta 24, 203.

Shockman, G. D., Kolb, J. J. \& ToenNies, G. (I958). Relations between bacterial cell wall synthesis, growth phase and autolysis. J. biol. Chem. 230, $96 \mathrm{I}$.

SмIтH, I. (1960). Silver nitrate reagent. In Chromatographic and Electrophoretic Techniques, and ed. Ed. by I. Smith, vol. I, p. 252. London: William Heinemann.

Strominger, J. L., Park, J. T. \& Thompson, R. E. (1959). Composition of the cell wall of Staphylococcus aureus: its relation to the mechanism of action of penicillin. J. biol. Chem. 234, 3263. 
Swallow, D. L. \& Abraham, E. P. (1958). Formation of $\epsilon$-(aminosuccinyl)-lysine from $\epsilon$-asparty!lysine from bacitracin A and from the cell walls of lactobacilli. Biochem. J. 70, 364 .

WhITE, P. J. (I966). The chemical composition of cell walls from Pediococcus cerevisiae and from a substrain that requires methicillin for growth. J. gen. Microbiol. 44, i.

WhITE, P. J. (1967). A strain of Pediococcus cerevisiae which requires methicillin for growth. J. gen. Microbiol.

WHITE, P. J. \& Nichol, C. A. (1963). Effects of uracil and thymidine on the development of resistance to 5 -fluorouracil in Pediococcus cerevisiae. J. Bact. 85, 97.

WISE, E. M. Jr. \& PARK, J. T. (1965). Penicillin: its basic site of action as an inhibitor of a peptide cross-linking reaction in cell wall mucopeptide synthesis. Proc. natn. Acad. Sci., U.S.A. 54, 75. 